Janusz Tomaszewski

ORCID: 0000-0002-4638-4818

Uniwersytet Wrocławski

\title{
Formowanie Wojsk Obrony Terytorialnej
}

DOI: 10.19195/1643-0328.26.5

Słowa kluczowe: obrona terytorialna, siły zbrojne, lekka piechota, zarządzanie kryzysowe, działania nieregularne, terytorialna służba wojskowa

\section{Wprowadzenie}

Wojska Obrony Terytorialnej (WOT) oficjalną działalność rozpoczęły 1 stycznia 2017 roku$^{1}$. Są piątym, oprócz wojsk lądowych, sił powietrznych, marynarki wojennej i wojsk specjalnych, rodzajem sił zbrojnych w Wojsku Polskim. Należy podkreślić, że jest to kolejna próba reaktywowania formacji istniejącej w Siłach Zbrojnych PRL i zlikwidowanej praktycznie u schyłku lat osiemdziesiątych XX wieku. Pierwszą podjęto już w 1990 roku. Planowano wówczas sformowanie brygad i pułków obrony regionalnej, pozostających w podporządkowaniu dowódców okręgów wojskowych. Zadaniem tych jednostek było przede wszystkim udzielanie wsparcia wojskom operacyjnym ${ }^{2}$.

W 1992 roku, po ratyfikacji przez Polskę Traktatu o konwencjonalnych siłach zbrojnych w Europie ${ }^{3}$, opracowano model restrukturyzacji Wojska Polskiego znany jako „Siły Zbrojne - 2005”. Zakładał on między innymi przemianowanie wojsk obrony regional-

${ }^{1}$ W tym dniu weszła w życie ustawa $\mathrm{z}$ dnia 16 listopada 2016 r. o zmianie ustawy o powszechnym obowiązku obrony Rzeczypospolitej Polskiej oraz niektórych innych ustaw, Dz.U. z 2016 r. poz. 2138.

2 R. Jakubczak, Współczesne Wojska Obrony Terytorialnej, Warszawa 2016, s. 74.

3 Traktat CFE został podpisany 19 listopada 1990 roku w Paryżu, wszedł w życie 17 lipca 1992 roku. Jego sygnatariuszami były wszystkie państwa członkowskie Paktu Północnoatlantyckiego i Układu Warszawskiego. Traktat ustanawiał pułapy uzbrojenia konwencjonalnego na obszarze Europy dla obu grup państw w stosunku 1:1 w pięciu wyróżnionych kategoriach do następujących wysokości: czołgi - 40 000, bojowe wozy opancerzone -60000 , systemy artyleryjskie -40000 , samoloty bojowe -13600 , śmigłowce uderzeniowe - 4000. Osiągnięcie określonych w Traktacie limitów miało się dokonać w ciągu 40 miesięcy po jego wejściu w życie. Polska otrzymała następujące limity: czołgi - 1730, bojowe wozy opancerzone - 2150, systemy artyleryjskie -1610 , samoloty bojowe -460 , śmigłowce uderzeniowe -130 . Szerzej zob. Traktat o konwencjonalnych siłach zbrojnych $w$ Europie/Treaty on Conventional Armed Forces in Europe, podpisany 19 listopada 1990 r. w Paryżu, „Zbiór dokumentów/Recueil de Documents” (PISM), 1991/XLVII, s. 126-166. 
nej na WOT oraz utworzenie w każdym z czterech okręgów wojskowych jednej brygady OT. Z chwilą wybuchu wojny na bazie każdej z tych jednostek zamierzano sformować 2-3 brygady OT, 3-5 pułków OT, pułk saperów i pułk pontonowy. Ogółem w skali całych sił zbrojnych miało powstać 8-12 brygad OT, 9-15 pułków OT, 4 pułki saperów i 4 pułki pontonowe. Poza tym planowano sformowanie samodzielnych batalionów OT, batalionów fortecznych i batalionów ochrony obiektów. Pierwsze trzy brygady OT utworzono w latach 1994-1995 na tak zwanej ścianie wschodniej. Miały one wzmocnić rozlokowane tam stosunkowo nieliczne wojska operacyjne ${ }^{4}$.

W styczniu 1999 roku opracowano nową koncepcję rozbudowy WOT, która przewidywała zorganizowanie 17 brygad OT rozlokowanych na terenie całego kraju, w poszczególnych województwach. Sam proces ich formowania podzielono na cztery etapy i powinien był się on zakończyć w 2012 roku. Docelowo WOT miały liczyć 10 tys. żołnierzy w okresie pokoju i 120 tys. żołnierzy w czasie wojny ${ }^{5}$.

Realizując ten projekt, w latach 1999-2001 utworzono 7 brygad OT. Jednak już w 2002 roku wstrzymano organizację kolejnych jednostek OT. Podjęto też decyzję o ograniczeniu liczebności WOT w okresie pokoju do 2-3 tys. żołnierzy i 50-70 tys. w czasie wojny. W 2003 roku rozwiązano brygadę OT w Gliwicach, a w 2005 roku brygadę OT w Mińsku Mazowieckim. W 2008 roku pozostałe 5 brygad, w związku z podjęciem decyzji o profesjonalizacji Sił Zbrojnych RP, najpierw zredukowano do batalionów OT, a następnie przeformowano $\mathrm{w}$ bataliony zmechanizowane i włączono do wojsk operacyjnych ${ }^{6}$. Wojska OT przestały istnieć, uznane zostały za zbędne, nieperspektywiczne.

Według koncepcji przyjętej przez MON odbudowa WOT jest odpowiedzią na pogarszającą się sytuację w środowisku bezpieczeństwa Polski, spowodowaną przede wszystkim przez agresywną politykę Rosji. Formacja ta w założeniach, będąc istotnym komponentem struktury militarnej państwa i zarazem ogniwem systemu bezpieczeństwa narodowego Rzeczypospolitej, ma wzmacniać jej siłę obronną.

Przyjmuje się, że celem strategicznym WOT powinno być

powszechne wojskowe przygotowanie i wykorzystanie zasobów ludzkich, materiałowych i przestrzeni lądowej do prowadzenia ochrony i obrony miejscowej na całym terytorium Polski dla zapewnienia skutecznego odstraszania, ochrony i obrony przed agresją i atakami grup terrorystycznych, a także niezwłocznego i skutecznego wsparcia władz i społeczeństwa w ratowaniu i zabezpieczeniu ludzi, mienia i środowiska w sytuacjach klęsk żywiołowych, katastrof technicznych i innych nieszczęść i potrzeb ${ }^{7}$.

W artykule omówione zostały następujące zagadnienia szczegółowe dotyczące formowania WOT: zadania, organizacja, sprzęt i uzbrojenie, zasady rekrutacji, szkolenie, terytorialna służba wojskowa.

4 Wojska Obrony Terytorialnej. Stan obecny. Pożądane kierunki zmian, oprac. M. Różański et al., Warszawa, luty 2018, s. 17, https://www.stratpoints.eu/publikacje/wojska-obrony-terytorialnej-stan-obecny-i-pozadanekierunki-zmian/ (dostęp: 23.03.2018).

5 Ibidem, s. 17-18; R. Rochowicz, Stara nazwa, nowa koncepcja, „Polska Zbrojna” 1999, nr 15, s. 14-15; W. Kaleta, Żołnierz w każdej wsi, „Polska Zbrojna” 2000, nr 15, s. 4-5.

6 Wojska Obrony Terytorialnej. Stan obecny..., s. 18.

7 J. Marczak, R. Jakubczak, Raport strategiczny: Siły Zbrojne RP w drugiej dekadzie XXI wieku. Koncepcja strategiczna Obrony Terytorialnej RP, Warszawa 2014, s. 74. 


\section{Zadania}

Zgodnie z wolą ustawodawcy organizowane od początku 2017 roku WOT w czasie pokoju przede wszystkim powinny być gotowe do realizacji zadań z zakresu zarządzania kryzysowego. Mają przeciwdziałać klęskom żywiołowym i likwidować ich skutki, prowadzić akcje ratownicze i poszukiwawcze, chronić zdrowie i życie ludzkie oraz mienie. Poza tym zadaniem tej formacji będzie prowadzenie działan antyterrorystycznych, w tym ochrona społeczności lokalnych przed skutkami ataków w cyberprzestrzeni, oraz propagowanie $\mathrm{w}$ społeczeństwie postaw patriotycznych i obronnych. Podczas wojny WOT powinny stanowić wsparcie dla regularnych pododdziałów, oddziałów i związków taktycznych Wojska Polskiego w strefie bezpośrednich działań bojowych, głównie w obronie. Ponadto mają być zdolne do prowadzenia na terenie kraju samodzielnych działań nieregularnych, przeciwdywersyjnych i przeciwdesantowych. Przewiduje się również ich udział w zabezpieczeniu przyjęcia i rozwinięcia sojuszniczych sił wzmocnienia w nakazanych rejonach ${ }^{8}$.

Nie jest to pełny katalog zadań możliwych do realizacji przez WOT. Korzystając z doświadczeń państw, w których podobne formacje działają dłużej, można go rozszerzyć o zadania dodatkowe, głównie z obszaru działań militarnych. Oto niektóre z nich":

1. zbieranie informacji o przeciwniku, naprowadzanie uderzeń i ocena ich skutków;

2. likwidacja skutków uderzeń przeciwnika;

3. tworzenie grup oporu na obszarach zajętych przez przeciwnika oraz wspieranie miejscowej ludności;

4. zabezpieczenie mobilizacyjnego i operacyjnego rozwinięcia wojsk;

5. wspieranie wojsk operacyjnych w prowadzeniu działań opóźniających;

6. wiązanie części sił przeciwnika;

7. przygotowanie do obrony newralgicznych rejonów;

8. ochrona ważnych obiektów i instalacji kluczowej infrastruktury państwa (obiektów wojskowych, lotnisk, portów, baz morskich, rafinerii, gazociągów itp.);

9. ochrona systemu logistycznego realizowanego na rzecz wojsk operacyjnych i OT;

10. zapewnienie przepustowości głównych linii komunikacyjnych i zabezpieczenie węzłów komunikacyjnych;

11. prowadzenie działań osłonowych (rozbudowa fortyfikacyjna rubieży i rejonów odpowiedzialności, budowa zapór, obrona niektórych rubieży i obiektów);

12. realizacja przedsięwzięć $\mathrm{w}$ ramach strategicznego i operacyjnego maskowania działań wojsk.

${ }^{8}$ Por. ustawa z dnia 16 listopada 2016 r. o zmianie ustawy o powszechnym obowiązku obrony Rzeczypospolitej Polskiej oraz niektórych innych ustaw; Zadania WOT, http://www.mon.gov.pl/obrona-terytorialna/o-nas/zadania-wot-n2016-12-27/ (dostęp: 5.02.2019).

9 Por. Wojska Obrony Terytorialnej. Stan obecny..., s. 31-32; A. Michalak, Cele, zadania, struktura i funkcje wojsk obrony terytorialnej w XXI wieku, „Bezpieczeństwo. Teoria i Praktyka” 2017, nr 3, s. 32-34; Z. Polcikiewicz, Wojska Obrony Terytorialnej w systemie bezpieczeństwa narodowego Polski, s. 408, http://cejsh. icm.edu.pl/cejsh/element/bwmetal.element.desklight-99a69fa5-32a6-42fc-8012-daa458d1c65f/c/Wojska_ obrony_terytorialnej_399-413.pdf (dostęp: 5.02.2019). 
Dowódca WOT jest właściwy w zakresie dowodzenia jednostkami i związkami organizacyjnymi tej formacji w czasie pokoju, sytuacji kryzysowej i wojny. Do jego zadań należy między innymi:

1. planowanie, organizowanie i prowadzenie szkolenia podległych jednostek wojskowych i związków organizacyjnych;

2. planowanie oraz organizowanie mobilizacyjnego i operacyjnego rozwinięcia oraz użycia Wojsk Obrony Terytorialnej;

3. przygotowanie sił i środków Wojsk Obrony Terytorialnej do działań bojowych;

4. wykonywanie zadań związanych z udziałem oddziałów i pododdziałów Wojsk Obrony Terytorialnej w zwalczaniu klęsk żywiołowych i likwidacji ich skutków, ochrony mienia, akcjach poszukiwawczych oraz ratowania lub ochrony zdrowia i życia ludzkiego, a także udziału w realizacji zadań z zakresu zarządzania kryzysowego;

5. współpraca $\mathrm{z}$ innymi organami i podmiotami w sprawach związanych z obronnością państwa ${ }^{10}$.

\section{Organizacja}

Zdecydowano, że organizacja WOT będzie ściśle powiązana z aktualnie istniejącym podziałem administracyjnym kraju. Łącznie powinno powstać 17 brygad OT: dwie w województwie mazowieckim i po jednej w pozostałych województwach. W ich szeregach docelowo ma służyć 53 tys. żołnierzy ${ }^{11}$, zarówno zawodowych, jak i żołnierzy nowego rodzaju czynnej służby wojskowej, czyli terytorialnej służby wojskowej.

Dowódca Wojsk Obrony Terytorialnej jest powoływany przez Prezydenta RP. Decyzja ta podlega jednak kontrasygnacie premiera. Na stanowisko dowódcy WOT został mianowany gen. Wiesław Kukuła ${ }^{12}$. Podlega on bezpośrednio (tymczasowo) ministrowi obrony narodowej. W docelowym modelu Sił Zbrojnych RP Dowództwo Wojsk Obrony Terytorialnej ma być usytuowane podobnie jak inne dowództwa rodzajów sił zbrojnych $^{13}$.

Pierwotny plan zakładał, że formowanie brygad OT będzie przebiegało w latach 2016-2019 w czterech etapach:

— w pierwszym (2016 rok) zamierzano utworzyć trzy brygady: w województwach podlaskim, lubelskim i podkarpackim;

10 WOT w systemie obronnym państwa, http://www.mon.gov.pl/obrona-terytorialna/pytania-i-odpowiedzi/wot-w-systemie-obronnym-panstwa-y2016-12-28/ (dostęp: 5.02.2019); Wojska Obrony Terytorialnej. Stan obecny..., s. 26-27.

${ }^{11}$ Według pierwotnych założeń prezentowanych przez MON WOT miały grupować 34 tys. żołnierzy. Następnie liczbę tę zwiększono do 50 tys., a później do 53 tys. Por. P. Wroński, Wojska Obrony Terytorialnej będą jeszcze liczniejsze. Macierewicz zapowiada 53 tys. żolnierzy za 3 lata, http://wyborcza.pl/7,75398,20975686,wojska-obrony-terytorialnej-beda-jeszcze-liczniejsze-antoni.html (dostęp: 10.02.2018).

12 Wcześniej w stopniu pułkownika dowodził Jednostką Wojskową Komandosów w Lublińcu.

13 WOT w systemie obronnym państwa... 
- w drugim (2017 rok) przewidywano zorganizowanie kolejnych trzech brygad: dwóch w województwie mazowieckim i jednej w województwie warmińsko-mazurskim;

— w trzecim (2018 rok) miało powstać pięć brygad: w województwach pomorskim, kujawsko-pomorskim, łódzkim, świętokrzyskim i małopolskim;

— w czwartym (2019 rok) planowano sformować aż sześć brygad: w województwach zachodniopomorskim, lubuskim, wielkopolskim, dolnośląskim, opolskim i śląskim ${ }^{14}$.

W 2017 roku Ministerstwo Obrony Narodowej skorygowało ten harmonogram, przesuwając na 2018 rok termin utworzenia brygad OT w województwach śląskim i wielkopolskim ${ }^{15}$. Przyjęto też, że do końca 2016 roku liczebność WOT osiągnie poziom około 3 tys. żołnierzy, by po kolejnych dwunastu miesiącach wzrosnąć do 18 tys., w grudniu 2018 roku do 35 tys., a w grudniu 2019 roku do 53 tys. ${ }^{16}$ Natomiast cały system WOT ostatecznie powinien zostać zbudowany do 2021 roku $^{17}$.

Całkowity koszt sformowania, wyekwipowania i funkcjonowania Wojsk Obrony Terytorialnej resort obrony narodowej pierwotnie oszacował na 3,6 mld zł: w 2016 roku - 394,4 mln zł; w 2017 roku - 630,7 mln zł; w 2018 roku - 1095,1 mln zł; w 2019 roku $-1482,8 \mathrm{mln} \mathrm{zl}^{18}$.

Brygady, tworzące szczebel operacyjny Wojsk Obrony Terytorialnej, mają mieć niejednolitą strukturę, jednak zasadniczy trzon jednostki powinny tworzyć: dowództwo i sztab, kompania dowodzenia, 3-5 batalionów lekkiej piechoty oraz pododdziały wsparcia i zabezpieczenia - kompania wsparcia, kompania saperów, kompania logistyczna, pluton medyczny. Brygada jako największa jednostka WOT, grupująca ponad 3 tys. żołnierzy, będzie stanowić element wsparcia operacyjnego i logistycznego pododdziałów niższego szczebla i zgrupowań bojowych prowadzących działania w danym rejonie, co ma gwarantować ich skuteczność ${ }^{19}$.

Szczeblem pośrednim w strukturze organizacyjnej Wojsk Obrony Terytorialnej ma być liczący 765 żołnierzy batalion lekkiej piechoty, w którego składzie przewiduje się następujące pododdziały: sztab, 3 kompanie lekkiej piechoty, kompanię specjalistyczną, kompanię logistyczną, pluton dowodzenia i pluton saperów-inżynieryjny. Dostępne informacje każą przypuszczać, że będą sformowane 63 bataliony. Na bazie pododdziałów batalionów zostaną też utworzone tak zwane zgrupowania zadaniowe WOT, przezna-

14 W 2016 roku w rzeczywistości miały powstać trzy bataliony OT, grupujące około 3 tys. żołnierzy. Uzbrojenie, wyposażenie i struktury Wojska Polskiego. Wojska Obrony Terytorialnej, http://militarium.net/uzbrojenie-wyposazenie-i-struktury-wojska-polskiego-wojska-obrony-terytorialnej/ (dostęp: 20.03.2018); Minister Antoni Macierewicz: 53 tys. żolnierzy WOT do 2019 r., http://www.polskatimes.pl/fakty/polityka/a/ministerantoni-macierewicz-53-tys-zolnierzy-wot-do-2019-r,11456054/ (dostęp: 20.03.2018).

15 Wojska Obrony Terytorialnej szybciej na zachodzie kraju, http://www.defence24.pl/wojska-obronyterytorialnej-szybciej-na-zachodzie-kraju (dostęp: 20.02.2018).

${ }^{16}$ Minister Antoni Macierewicz...

17 Plany budowy WOT, http://www.mon.gov.pl/obrona-terytorialna/o-nas/plany-budowy-wot-q2016-12-27/. (dostęp: 20.03.2018).

18 WOT. Najczéściej zadawane pytania, http://www.wojsko-polskie.pl/pl/articles/wojska-obrony-terytorialnej-p/najczesciej-zadawanepytania-2016-12-06/ (dostęp: 5.02.2019); P. Wroński, op. cit.

$19 \mathrm{http} / / /$ militarium.net/tag/obrona-terytorialna/ (dostęp: 20.03.2018). 
czone do wykonywania ściśle określonych zadań i wsparte w razie potrzeby przez dodatkowe siły i sprzęt ${ }^{20}$.

Podstawowymi formacjami WOT będą liczące 150 żołnierzy kompanie lekkiej piechoty — zasadnicze pododdziały funkcjonujące na poziomie powiatu. Planuje się utworzenie 364 kompanii. Każda z nich ma mieć określony profil działania, między innymi ogólnowojskowy, miejski, górski czy wodny. Powinno to wynikać ze specyfiki środowiska geograficznego i demograficznego, tak zwanego stałego rejonu odpowiedzialności (SRO), w jakim przyjdzie im operować. Do szczebla kompanii SRO będzie w zasadzie pokrywał się z administracyjnymi granicami powiatu, a w dużych miastach - gminy. Profil pododdziału zdecyduje w określonym zakresie o jego wyposażeniu, w tym indywidualnym żołnierzy, a także programie szkolenia. Kompania OT będzie miała w swym składzie: dowództwo, 3 plutony lekkiej piechoty, pluton wsparcia ogniowego i drużynę zabezpieczenia $^{21}$.

Pluton lekkiej piechoty powinien liczyć 40 żołnierzy i grupować 3 drużyny (sekcje) lekkiej piechoty i drużynę wsparcia. Pluton wsparcia ogniowego (30 żołnierzy) ma się składać z 4 drużyn: dwóch przeciwpancernych oraz po jednej granatników automatycznych i karabinów maszynowych ${ }^{22}$.

Najmniejszym pododdziałem w WOT będzie dwunastoosobowa drużyna (sekcja) lekkiej piechoty w składzie: dowódca drużyny (sekcji), zastępca dowódcy drużyny (sekcji), starszy strzelec wyborowy-zwiadowca, strzelec wyborowy-zwiadowca, starszy saper, saper, starszy ratownik, ratownik, starszy radiotelegrafista, radiotelegrafista, celowniczy, strzelec $^{23}$.

Dokonując oceny przyjętego modelu struktury i dyslokacji WOT, należy przychylić się do tych opinii formułowanych w literaturze przedmiotu, które wskazują, że prowadzi on do nadmiernego rozproszenia pododdziałów, zwłaszcza kompanii. W konsekwencji utrudni to ich szkolenie, ale przede wszystkim ześrodkowanie i dowodzenie, jeśli zaistnieje potrzeba działania w ramach większych komponentów - batalionów czy brygad ${ }^{24}$. Zasadny wydaje się też pogląd, że brygady OT powinny zostać utworzone nie we wszystkich województwach, lecz tylko w tych, w których zagrożenia militarne i niemilitarne są największe. Oddziały te w czasie pokoju powinny funkcjonować jako samodzielne, zwarte formacje, rozmieszczone w miarę możliwości w jednym garnizonie ${ }^{25}$.

Formowanie Wojsk Obrony Terytorialnej nie przebiega, niestety, zgodnie z przyjętymi ustaleniami. Owszem, terminowo organizowane są dowództwa poszczególnych bry-

20 Ibidem; Struktura batalionu lekkiej piechoty, https://obronanarodowa.pl/download/struktura-batalionu-lekkiej-piechoty/struktura-batalionu-lekkiej-piechoty.pdf (dostęp: 13.02.2018).

21 Ibidem; http://militarium.net/tag/obrona-terytorialna/ (dostęp: 20.03.2018).

22 Struktura batalionu...

23 Ibidem; http://militarium.net/tag/obrona-terytorialna/ (dostęp: 20.03.2018).

24 Z. Polcikiewicz, op. cit., s. 410.

25 Ibidem. 
gad $\mathrm{OT}^{26}$ i niektórych jednostek wchodzących w ich skład. Te jednak powstają głównie w oparciu o kadrę zawodową, przenoszoną tu z innych rodzajów Sił Zbrojnych RP.

Dużo gorzej wygląda sprawa naboru ochotników do terytorialnej służby wojskowej. Na przełomie lat 2016 i 2017, o czym była już mowa, pierwsze trzy brygady OT tworzone na „ścianie wschodniej” powinny były liczyć ich około 3 tys. Tymczasem, według informacji przekazywanych przez MON, w połowie maja 2017 roku Wojska Obrony Terytorialnej grupowały ogółem 1379 żołnierzy, w tym 580 zawodowych i 799 ochotników ${ }^{27}$.

$\mathrm{Z}$ kolei $\mathrm{w}$ połowie stycznia 2018 roku resort obrony narodowej przedstawił dane, z których wynikało, że w omawianej formacji pełniło służbę niemal 8 tys. żołnierzy. W tej liczbie miało się znajdować 1470 żołnierzy zawodowych (ponad 18\% stanu osobowego WOT) i około 6,5 tys. żołnierzy terytorialnej służby wojskowej ${ }^{28}$. A przecież, według założeń MON, w tym czasie powinno już funkcjonować 6 brygad OT, liczących łącznie 18 tys. żołnierzy. W rzeczywistości było ich aż o 10 tys. (55\%) mniej, niż początkowo prognozowano. Żadna też z formowanych wówczas brygad nie została w pełni skompletowana. W tych powstających najwcześniej, w województwach podlaskim, lubelskim i podkarpackim, obsada stanowisk etatowych wynosiła od 45 do $80 \%{ }^{29}$.

W następnych miesiącach liczebność WOT wzrastała powoli i 19 lipca 2018 roku kształtowała się na poziomie 11,6 tys. żołnierzy. Wśród nich było 2100 zawodowych wojskowych $(22,1 \%)$ i 9,5 tys. żołnierzy terytorialnej służby wojskowej ${ }^{30}$. Dwukrotnie większy niż pierwotnie zakładano i wciąż rosnący udział kadry zawodowej w szeregach nowego komponentu SZ RP, kierowanej tu z jednostek liniowych, może budzić obawy, czy nie wpłynie to negatywnie na ich gotowość bojową.

W styczniu 2018 roku gen. W. Kukuła, występując na posiedzeniu sejmowej Komisji Obrony Narodowej, przedstawił nową, skorygowaną prognozę dotyczącą wzrostu szeregów WOT. Poinformował, że do końca 2018 roku w tym segmencie Wojska Polskiego będzie służyło 21 tys. żołnierzy, rok później - 31,5 tys., a pod koniec 2020 roku 53 tys. ${ }^{31}$ Przyznał więc, że osiągniecie początkowo zakładanej maksymalnej liczby żoł-

${ }^{26}$ Do 15 stycznia 2018 roku utworzono dowództwa trzynastu brygad OT. Por. Jednostki wojskowe, https://www. jednostki-wojskowe.pl (dostęp: 12.02.2018); Formowanie brygad OT w Polsce centralnej, http://www.mon.gov.pl/aktualnosci/artykul/najnowsze/formowanie-brygad-ot-w-polsce-centralnej-m2018-01-15/ (dostęp: 20.03.2018).

27 M. Miłosz, Wojska Obrony Terytorialnej - 6 faktów na temat piątego rodzaju sił zbrojnych, http:// wiadomosci.dziennik.pl/wydarzenia/artykuly/551045,wojska-obrony-terytorialnej-koszty-struktura,html (dostęp: 5.02.2019).

28 Ponad 30\% „terytorialsów” to osoby, które nie przekroczyły 25. roku życia. Średnia wieku ochotników to 31 lat. Kobiety stanowią wśród nich 10\%. Co trzeci żołnierz terytorialnej służby wojskowej legitymuje się wyższym wykształceniem, co drugi — średnim, a około 19\% studiuje. Są między nimi lekarze, nauczyciele, pracownicy administracji samorządowej. Por. Formowanie brygad OT...; Rok terytorialsów, http://www.polska-zbrojna.pl/home/articleshow/24440?t=Rok-terytorialsow (dostęp: 16.02.2018).

${ }^{29}$ Ibidem.

30 MON: aktualnie w WOT służy 11,6 tys. żotnierzy, https://www.wnp.pl/przemysl-obronny/mon-aktualnie-w-wot-sluzy-11-6-tys-zolnierzy,327297_1_0_0.html (dostęp: 10.02.2019).

31 J. Tańska, W Sejmie podsumowano rok funkcjonowania WOT, http://www.polska-zbrojna.pl/home/ articleshow/24497?t=W-Sejmie-podsumowano-rok-funkcjonowania-WOT (dostęp: 21.02.2018). Z kolei w grudniu 2018 roku MON ogłosiło, że do końca 2019 roku w szeregach WOT będzie służyć 26 tys. żołnie- 
nierzy WOT opóźni się przynajmniej o rok. Biorąc pod uwagę dotychczasowe tempo pozyskiwania ochotników do wojskowej służby terytorialnej, można mieć obawy, czy ten nowy termin zostanie dotrzymany.

Resort obrony narodowej dokonał również istotnej korekty kosztów związanych $\mathrm{z}$ utworzeniem i funkcjonowaniem Wojsk Obrony Terytorialnej. Te podawane w momencie startu całego przedsięwzięcia okazały się mocno niedoszacowane. W 2017 roku nakłady finansowe na WOT zostały zwiększone z 630,7 mln zł do $900 \mathrm{mln}$ zł. Stanowiło to $2,4 \%$ całego budżetu obronnego Sił Zbrojnych $\mathrm{RP}^{32}$. W 2018 roku wydatki na WOT zamiast planowanych 1095,1 mln zł miały wynieść 1343,7 mln zł, przekraczając 3,2\% całości środków budżetowych przeznaczonych na finansowanie zadań obronnych ${ }^{33}$.

Uwzględniając fakt, że procedura naboru kandydatów do terytorialnej służby wojskowej nie zostanie zakończona w 2019 roku, lecz będzie kontynuowana jeszcze w 2020 roku, należy się spodziewać dalszego wzrostu nakładów finansowych na budowę struktury organizacyjnej WOT, ale także przeznaczonej dla nich infrastruktury (między innymi koszar, ośrodków szkoleniowych, magazynów), której praktycznie nie ma. Uszczupli to zapewne wielkość środków, jaka będzie do dyspozycji wojsk operacyjnych, co może opóźnić ich modernizację techniczną i planowany rozwój liczebny.

\section{Sprzęt i uzbrojenie}

Należy podkreślić, że wszystkie pododdziały i oddziały WOT, od drużyny (sekcji) po brygadę, pod względem struktury, wyposażenia i uzbrojenia będą jednostkami lekkiej piechoty. Na ich uzbrojeniu znajdą się między innymi: pistolety PR-15 Ragun, karabinki MSBS Grot i Beryl (w tym z granatnikami podwieszanymi), subkarabinki Mini Beryl, karabiny wyborowe Bor (Alex), Sako TRG22 i wielkokalibrowe karabiny wyborowe Tor, granatniki samodzielne GSBO-40 i rewolwerowe granatniki ręczne RPG-40. Broń wsparcia mają stanowić karabiny maszynowe UKM-2000P i moździerze LM-60D Pluton. Z informacji przekazywanych przez przedstawicieli WOT wynika, że rozważane jest wyposażenie tej formacji w nowe karabinki maszynowe w miejsce karabinów maszynowych UKM 2000P, nowe moździerze lekkie oraz drony rozpoznawcze ${ }^{34}$.

Natomiast do zwalczania środków napadu powietrznego mają służyć przeciwlotnicze zestawy artyleryjsko-rakietowe ZUR-23-2 i przenośne zestawy rakietowe Grom/

rzy. M. Miłosz, MON zwiększyło górny limit żołnierzy WOT o 10 tys. ludzi. Zaraz po publikacji DGP, https:// wiadomosci.dziennik.pl/wydarzenia/artykuly/588,wot-mon-armia.html (dostęp: 10.02.2019).

32900 mln złotych w budżecie WOT na 2017 r. W roku kolejnym 1,3 mld złotych, http://www.defence24. pl/mon-900-mln-zlotych-w-budzecie-wot-na-2017-r-w-roku-kolejnym-1.3-mld-zl (dostęp: 10.04.2018).

${ }^{33} \mathrm{Na}$ finansowanie dowództwa WOT i podporządkowanych mu jednostek organizacyjnych zaplanowano w budżecie MON kwotę 567,9 mln zł. Ponadto kolejne 775,8 mln zł ma zostać wydatkowanych „na realizację zadań w ramach centralnych planów rzeczowych na rzecz jednostek WOT”, czyli na inwestycje MON i Sił Zbrojnych RP. Ibidem.

${ }^{34}$ Ibidem; Zobacz, w jaki sprzęt będą wyposażeni żotnierze WOT, http://superbiz.se.pl/nowoczesne-technologie/zobacz-w-jaki-sprzet-beda-wyposazeni-zolnierze-wot-galeria_918160.html (dostęp: 5.04.2018). 
GromM, Piorun i Strzała-2M. Arsenał broni przeciwpancernej ma zawierać granatniki przeciwpancerne jednorazowego i wielokrotnego użytku, zestawy przeciwpancernych pocisków kierowanych Fagot oraz miny denne i przeciwburtowe ${ }^{35}$.

Jest mało prawdopodobne, aby jednostki OT zostały wyposażone $\mathrm{w}$ cięższe rodzaje uzbrojenia, takie jak moździerze średnie lub ciężkie ${ }^{36}$. Tych bowiem ledwo wystarcza na wyekwipowanie regularnych pododdziałów wojsk aeromobilnych i zmechanizowanych (zmotoryzowanych). Mało realna wydaje się też zapowiedź MON dotycząca wyposażenia formacji OT w najnowocześniejsze w całych Siłach Zbrojnych RP zestawy przeciwpancernych pocisków kierowanych Spike-LR ${ }^{37}$. Zasoby tej broni są tak szczupłe, że nie pozwalają zaopatrzyć w nią nawet wszystkich pierwszorzutowych pododdziałów wojsk operacyjnych.

Sprzęt i uzbrojenie należące do pododdziałów WOT mają być przechowywane w magazynach jednostek wojskowych oraz w Wojskowych Oddziałach Gospodarczych, ewentualnie $\mathrm{w}$ komendzie policji na terenie powiatu, w którym operuje dany pododdział OT lub w miejscu stacjonowania dowództwa batalionu OT. Natomiast umundurowanie żołnierze WOT powinni przechowywać w miejscu swojego zamieszkania ${ }^{38}$.

Transport Wojsk Obrony Terytorialnej mają stanowić między innymi samochody ciężarowo-terenowe i osobowo-terenowe oraz motocykle, quady i skutery śnieżne ${ }^{39}$.

\section{Zasady rekrutacji}

W szeregi WOT może wstąpić osoba, która: jest pełnoletnia, legitymuje się obywatelstwem polskim, posiada zdolność fizyczną i psychiczną do pełnienia czynnej służby wojskowej, nie była karana za przestępstwo umyślne, nie była przeznaczona do służby zastępczej, nie pełni innego rodzaju czynnej służby wojskowej i nie posiada nadanego przydziału kryzysowego, ma odpowiednie wykształcenie: wyższe - jeśli ubiega się o objęcie stanowiska w korpusie oficerów, co najmniej średnie - jeśli chce podjąć służbę na stanowisku podoficerskim, i co najmniej podstawowe — starając się o służbę w korpusie szeregowych ${ }^{40}$.

Powołanie do terytorialnej służby wojskowej może być uzależnione od spełnienia przez kandydata jeszcze innych dodatkowych warunków, między innymi posiadania wymaganych przez wojsko kwalifikacji do objęcia konkretnego stanowiska służbowego

35 http://militarium.net/tag/obrona-terytorialna/ (dostęp: 20.03.2018).

36 https://holicin.livjournal.com/11697287.html\#/11697287.html (dostęp: 30.03.2018); Terytorialsi bez ciężkiej artylerii, $z$ pociskami przeciwpancernymi, http://www.defence24.pl/dwot-terytorialsi-bez-ciezkiejartylerii-z-pociskami-przeciwpancernymi (dostęp: 2.03.2018).

37 Ibidem; Gen. Kukuła: spikei w WOT obstugiwane przez żolnierzy zawodowych, http://defence24.pl/ gen-kukula-spikei-w-wot-obslugiwane-przez-zolnierzy-zawodowych (dostęp:17.03.2018).

38 WOT. Wyposażenie i uzbrojenie, http://www.mon.gov.pl/obrona-terytorialna/pytania-i-odpowiedzi/ wyposazenie-i-uzbrojenie-I2016-12-28/ (dostęp: 5.02.2019); Wojska Obrony Terytorialnej. Stan obecny..., s. 25.

39 WOT. Wyposażenie i uzbrojenie...

40 WOT. Wymagania, http://www.mon.gov.pl/obrona-terytorialna/dolacz-do-nas/wymagania-f2016-12-28/ (dostęp: 5.02.2019). 
czy też złożenia wniosku wraz z ankietą bezpieczeństwa o przeprowadzenie rutynowego postępowania sprawdzającego $^{41}$.

Pierwszeństwo służby w WOT mają byli żołnierze zawodowi, członkowie proobronnych organizacji pozarządowych oraz absolwenci tak zwanych klas wojskowych szkół realizujących programy przysposobienia obronnego lub edukacji dla bezpieczeństwa ${ }^{42}$.

Kandydaci zainteresowani służbą w WOT, zarówno żołnierze rezerwy, jak i ochotnicy, po zgłoszeniu się do właściwej dla miejsca zamieszkania Wojskowej Komendy Uzupełnień, złożeniu stosownego wniosku wraz z wymaganymi dokumentami do jej komendanta, kwalifikowani są przez komisję rekrutacyjną do terytorialnej służby wojskowej. Nabór ma charakter konkursowy i obejmuje analizę złożonych dokumentów oraz rozmowę kwalifikacyjną. Po pozytywnym przejściu tego etapu rekrutacji i otrzymaniu tak zwanej rekomendacji powołania kandydaci kierowani są do wojskowej pracowni psychologicznej w celu wydania orzeczenia o braku przeciwwskazań do pełnienia czynnej służby lub służby na stanowiskach wymagających szczególnych predyspozycji psychofizycznych. Otrzymanie takiego dokumentu otwiera im drogę do służby w $\mathrm{WOT}^{43}$.

Ochotnicy, którzy nie mają orzeczonej zdolności do czynnej służby wojskowej lub posiadają kategorię D tej zdolności, dodatkowo są kierowani do wojskowej komisji lekarskiej w celu określenia ich zdolności do pełnienia czynnej służby wojskowej. Pozytywna opinia komisji umożliwia ich powołanie do terytorialnej służby wojskowej. Mają oni obsadzać głównie stanowiska wymagające specjalistycznej wiedzy ${ }^{44}$.

W przepisach wskazano, że kandydaci, którzy wcześniej nie pełnili czynnej służby wojskowej i nie złożyli przysięgi wojskowej, mogą uzyskać powołanie wyłącznie na stanowiska służbowe w korpusie szeregowych ${ }^{45}$.

\section{Szkolenie}

Wszystkie osoby zakwalifikowane do służby w WOT, z wyłączeniem żołnierzy zawodowych, mają obowiązek stawienia się na szkolenie wojskowe: rezerwiści na ośmiodniowe (cztery razy po dwa dni) szkolenie wyrównawcze, które ma uzupełnić wcześniej zdobytą przez nich wiedzę wojskową; natomiast reszta ochotników, bez doświadczenia wojskowego, na szesnastodniowe szkolenie podstawowe. To ostatnie może być przeprowadzone w jednym z dwóch wariantów: stacjonarnym (szesnaście dni szkoleniowych realizowanych w jednym bloku) lub weekendowym (szesnaście dni szkoleniowych realizowanych

41 Ibidem.

42 WOT. Pierwszeństwo w powołaniu, http://www.mon.gov.pl/obrona-terytorialna/dolacz-do-nas/pierszenstwo-w-powolaniu-g2016-12-28/ (dostęp: 5.02.2019).

43 WOT. Procedury rekrutacji, http://www.mon.gov.pl/obrona-terytorialna/dolacz-do-nas/proceduryrekrutacji-r2016-12-28/ (dostęp: 5.02.2019).

44 Ibidem.

45 Ibidem. 
w ciągu ośmiu weekendów). W ostatnim dniu szkolenia praktycznego przeprowadza się przysięgę wojskową ${ }^{46}$.

Szkolenie podstawowe ma pozwolić na osiągniecie przez żołnierzy terytorialnej służby wojskowej następujących standardów:

1. opanowanie podstawowych zasad zachowania się w warunkach bojowych oraz indywidualnego działania podczas wybranych działań taktycznych;

2. przysposobienie do bezpiecznej realizacji zadań ogniowych z wykorzystaniem etatowej broni strzeleckiej;

3. opanowanie podstawowych umiejętności i przyswojenie wiedzy z zakresu zabezpieczenia bojowego, logistycznego i medycznego;

4. przygotowanie do samodzielnego doskonalenia sprawności fizycznej;

5. przyswojenie zasad żołnierskiego zachowania się ${ }^{47}$.

Przedmiotowa tematyka szkolenia podstawowego obejmuje między innymi: podstawy wychowania obywatelskiego i wojskowego (regulaminy, kształcenie obywatelskie, profilaktyka i dyscyplina wojskowa); szkolenie bojowe (strzeleckie, inżynieryjno-saperskie, medyczne, rozpoznanie i armie innych państw, obrona przed bronią masowego rażenia, powszechna obrona przeciwlotnicza, łączność, terenoznawstwo, ochrona i obrona obiektów, wychowanie fizyczne); szkolenie logistyczne (zabezpieczenie logistyczne, ochrona środowiska, profilaktyka pożarowa); szkolenie ogólne (prawne, bhp, ochrona informacji niejawnych $)^{48}$.

Zgodnie z przyjętymi założeniami szkolenie podstawowe będzie się odbywać w jednostkach wojskowych oraz centrach i ośrodkach szkolenia WOT. Ma być ono organizowane w czasie określonym porządkiem dnia zatwierdzonym przez dowódców (komendantów) tych placówek ${ }^{49}$. W grudniu 2018 roku rozpoczął się wstępny etap formowania Centrum Szkolenia WOT w Toruniu ${ }^{50}$.

W przyszłości, po 2020 roku, w miejsce szkolenia wyrównawczego i podstawowego przewiduje się uruchomienie w Centrum Szkolenia WOT w Toruniu stacjonarnego dziewięciotygodniowego podstawowego kursu lekkiej piechoty, który po zakończeniu szkolenia w obecnym kształcie będą zobligowani zaliczyć wszyscy starający się o przyjęcie do terytorialnej służby wojskowej ${ }^{51}$.

Ukończenie szkolenia wyrównawczego i podstawowego stanowi swoistą przepustkę do dalszego, tym razem trzyletniego, cyklu szkolenia, podzielonego na trzy dwunastomiesięczne okresy. W każdym z nich żołnierze WOT przez 22 dni mają zgłębiać wiedzę

46 Zakres wiedzy teoretycznej obowiązującej kandydata do Terytorialnej Stużby Wojskowej (tymczasowy), Warszawa 2017, s. 5, http://warszawapraga.wku.wp.mil.pl/files/warszawapraga/file/wot/materiały_tsw.pdf (dostęp: 25.04.2018).

47 Ibidem.

48 Ibidem, s. 6-128.

49 Ibidem, s. 5.

50 Pierwsze kursy mają zostać uruchomione w 2019 roku. Centrum Szkolenia WOT stawia na mobilność, https://polska-zbrojna.pl/home/articleshow/27082?t=Centrum-Szkolenia-WOT-stawia-na-mobilnosc (dostęp: 10.02.2019).

51 Rok terytorialsów... 
teoretyczną ${ }^{52}$, a przez następne czternaście doskonalić swoje umiejętności w warunkach poligonowych ${ }^{53}$.

W pierwszym roku ma to być szkolenie indywidualne, ukierunkowane przede wszystkim na nauczenie żołnierzy WOT podstaw działania lekkiej piechoty oraz taktyki wojskowej i strzelania. Będzie się ono odbywać w miejscu stacjonowania poszczególnych kompanii OT, czyli na szczeblu powiatu. W drugim roku przewiduje się szkolenie specjalistyczne, realizowane w ośrodkach szkolenia działających przy dowództwach brygad. W opracowanym przez MON i liczącym kilkadziesiąt pozycji katalogu specjalności, jakie mogą zdobyć żołnierze terytorialnej służby wojskowej, znalazły się między innymi: kierowca, strzelec wyborowy, skoczek spadochronowy, nurek, płetwonurek, ratownik pola walki czy operator maszyn i urządzeń dźwigowo-transportowych. W przyszłości lista ta ma się wydłużyć o kolejne specjalności, na przykład rozpoznanie meteorologiczne, przygotowywanie i zabezpieczanie lądowisk polowych, naprowadzanie zrzutów spadochronowych. Trzeci rok będzie etapem szkolenia zespołowego, rozwijania umiejętności taktycznych w zakresie walki oraz zgrywania pododdziałów na poziomie plutonu, kompanii i batalionu, $\mathrm{z}$ wykorzystaniem poligonowych ośrodków szkolenia ${ }^{54}$.

Tak więc w pierwszych trzech latach po wstąpieniu do WOT żołnierze tej formacji będą szkolić się przez co najmniej $124 \mathrm{dni}^{55}$. W określonych specjalnościach czas ten zostanie przedłużony o kolejne $30-60 \mathrm{dni}^{56}$. Wszyscy, którzy zaliczą cały cykl szkolenia, uzyskają stosowny certyfikat oraz status combat ready.

W ciągu pierwszych trzech lat służby żołnierze WOT ukończą też szkolenie SERE ${ }^{57}$, które ma ich przysposobić do przetrwania praktycznie w każdych warunkach, zarówno na polu walki, jak i poza nim. Będzie ono prowadzone na trzech poziomach zaawansowania: A, B, C. W pierwszym roku służby wszyscy „terytorialsi” zostaną objęci szkoleniem na poziomie A. Natomiast $\mathrm{w}$ trzecim roku przejdą szkolenie na poziomie B, a strzelcy wyborowi dodatkowo na poziomie C. Kolejne poziomy zaawansowania mają być kontynuacją poprzednich ze wzrostem ich złożoności i stopnia trudności ${ }^{58}$.

Przewiduje się, że szkolenia żołnierzy WOT będą prowadzili nie tylko instruktorzy i inni fachowcy z poszczególnych brygad i batalionów OT, lecz także specjaliści wcho-

52 Jest to tak zwane szkolenie rotacyjne, realizowane przez jedenaście weekendów po dwa dni (sobota i niedziela).

$53 \mathrm{~W}$ ramach tak zwanego szkolenia zintegrowanego.

54 Terytorialsi rozpoczynaja szkolenie indywidualne, http://www.mon.gov.pl/aktualnosci/artykul/najnowsze/terytorialsi-rozpoczynaja-szkolenie-indywidualne-f2017-06-10/ (dostęp: 5.02.2019); http://wiis. org.pl/index.php?option=com_content@view=article@id=82:w-warszawa (dostęp: 11.02.2018); P. Glińska, M. Kowalska-Sendek, WOT - misja, struktura, szkolenie, http://www.polska-zbrojna.pl/home/articleshow/22674?t=WOT-misja-struktura-szkolenie (dostęp: 19.03.2018).

55 Uwzględniając szesnastodniowe szkolenie podstawowe. http://wiss.org.pl/index.php?option=com_ content@view=article@id=82:w-warszawa (dostęp: 11.02.2018).

56 Ibidem.

57 Nazwa pochodzi od pierwszych liter wyrazów: survival (przetrwanie w niesprzyjającym środowisku), evasion (przeciwdziałanie przechwyceniu przez nieprzyjaciela), resistance (przeciwdziałanie wykorzystaniu w wypadku wzięcia do niewoli), escape (ucieczka lub dotarcie do macierzystego oddziału).

58 Terytorialsi rozpoczynaja szkolenie indywidualne... 
dzący w skład tak zwanych Mobilnych Zespołów Szkoleniowych. Ci ostatni mają przede wszystkim zająć się szkoleniem kadry dowódczej i instruktorów WOT oraz żołnierzy w wybranych specjalnościach wojskowych. Będą przekazywali specjalistyczną wiedzę z zakresu prowadzenia działań w rejonach słabo zurbanizowanych, leśnych i w górach (tak zwana taktyka zielona), walki w mieście (tak zwana taktyka czarna) oraz ochrony infrastruktury krytycznej i ratownictwa. Celem stworzenia Mobilnych Zespołów Szkoleniowych jest także wypracowanie wniosków i weryfikacja przydatności wyposażenia i uzbrojenia żołnierzy oraz bazy szkoleniowej wykorzystywanej przez WOT. Będą też odpowiadać za organizację oraz prowadzenie ćwiczeń i sprawdzianów kadry zawodowej i żołnierzy terytorialnej służby wojskowej. $Z$ dostępnych informacji wynika, i zespoły te mają działać na terenie całej Polski i będą podlegać bezpośrednio dowództwu WOT ${ }^{59}$.

W Mobilnych Zespołach Szkoleniowych znajdą pracę głównie byli operatorzy wojsk specjalnych z doświadczeniem bojowym, którzy mają kwalifikacje specjalistyczne, na przykład ratownika pola walki, strzelca wyborowego, łącznościowca, a także przedstawiciele innych służb mundurowych, między innymi wojskowi z pododdziałów zabezpieczenia desantowego czy funkcjonariusze z pododdziałów antyterrorystycznych. Wszyscy oni będą zatrudnieni jako pracownicy cywilni z możliwością jednoczesnego pełnienia terytorialnej służby wojskowej ${ }^{60}$.

Żołnierze WOT, którzy chcieliby otrzymać szlify oficerskie w tej formacji, muszą ukończyć przeznaczony specjalnie dla nich trzynastomiesięczny kurs, podzielony na cztery etapy. Program szkolenia („Agrykola”) obejmuje między innymi metodykę dowodzenia, taktykę, topografię, rozpoznanie i łączność. Po zdaniu egzaminu na oficera absolwenci kursu zostaną awansowani do stopnia podporucznika ${ }^{61}$. Pierwsze takie kursy, z udziałem 96 żołnierzy WOT, w tym jedenastu kobiet, rozpoczęły się w listopadzie 2017 roku w Akademii Wojsk Lądowych we Wrocławiu oraz Wojskowej Akademii Technicznej w Warszawie. W 2018 roku resort obrony narodowej zaplanował uruchomienie kolejnych kursów oficerskich dla 280 żołnierzy terytorialnej służby wojskowej ${ }^{62}$. Natomiast spełniający określone wymagania kandydaci na podoficerów WOT będą kierowani na szkolenie kursowe trwające dziewięć miesięcy ${ }^{63}$.

59 M. Kowalska-Sendek, Byli specjalsi utworza Mobilny Zespół Szkoleniowy WOT, http://www.polskazbrojna.pl/home/articleshow/21694?t=Byli-specjalsi-utworza-Mobilny-Zespol-Szkoleniowy-WOT (dostęp: 20.03.2018); Byli specjalsi wyszkola Obronę Terytorialna, http://www.dziennikpolski24.pl/aktualnosci/a/ byli-specjalsi-wyszkola-obrone-terytorialna, 11760011/ (dostęp: 7.03.2018).

60 Ibidem.

${ }^{61}$ Kandydaci na oficerów muszą legitymować się wykształceniem wyższym magisterskim oraz ukończonym szkoleniem podstawowym. Por. Terytorialsi zdobywaja oficerskie szlify, http://www.polska-zbrojna. $\mathrm{pl} /$ home/articleshow/24394?t=Terytorialsi-zdobywaja-oficerskie-szlify (dostęp: 19.04.2018).

${ }^{62}$ Ibidem; Rok terytorialsów...

${ }^{63}$ Nabór na pierwszy taki kurs ogłoszono w październiku 2017 roku. Zgłoszenia przyjmowano do 15 listopada 2017 roku tylko od osób cywilnych, mających co najmniej średnie wykształcenie. Dla kandydatów, którzy będą się szkolić w grupie osobowej pancerno-zmechanizowanej, przeznaczono 50 miejsc. Na miejsce kursu wyznaczono Szkołę Podoficerską Wojsk Lądowych w Poznaniu. Absolwenci kursu otrzymają stopień kaprala, http://spwl.wp.mil.pl/57.html (dostęp: 5.04.2018); R.Ch., Wojsko poszukuje 50 kandydatów na podoficerów WOT, 
Istotnym problemem rzutującym na efektywność procesu szkoleniowego żołnierzy WOT jest dalece niewystarczająca infrastruktura do ćwiczeń oraz pozyskiwania wiedzy teoretycznej. Za mało jest strzelnic i poligonów, z których mogłaby samodzielnie korzystać cała formacja. Podobnie rzecz się ma z systemami symulacyjnymi pola walki, trenażerami czy wideostrzelnicami. Są one nieliczne i w pierwszej kolejności udostępniane wojskom operacyjnym. Sytuację tę dodatkowo komplikuje odsuwanie w czasie uruchomienia Centrum Szkolenia WOT.

\section{Terytorialna służba wojskowa}

Terytorialna służba wojskowa jest nowym rodzajem czynnej służby wojskowej. Czas jej trwania wynosi od roku do sześciu lat i może zostać przedłużony na kolejny okres na wniosek lub za zgodą żołnierza OT lub przez dowódcę jednostki wojskowej, w której żołnierz OT odbywa służbę. Można ją pełnić w sposób rotacyjny $-\mathrm{w}$ jednostce wojskowej bądź związkach organizacyjnych WOT, na określonym stanowisku służbowym, co najmniej raz w miesiącu przez dwa dni, w czasie wolnym od pracy ${ }^{64}$, oraz w sposób dyspozycyjny - poza jednostką wojskową, wykonując swoją pracę lub inne obowiąz$\mathrm{ki}$, jednocześnie pozostając $\mathrm{w}$ gotowości, by stawić się do służby rotacyjnej w terminie i miejscu wskazanym przez właściwego dowódcę ${ }^{65}$.

Żołnierze, którzy wcześniej nie odbywali czynnej służby wojskowej, w pierwszym okresie po przyjęciu do WOT pełnią terytorialną służbę rotacyjnie przez szesnaście dni, podczas których, o czym była już mowa, odbywają szkolenie podstawowe i składają przysięgę wojskową. Stawienie się kandydata do terytorialnej służby wojskowej dowódca jednostki wojskowej stwierdza w specjalnym rozkazie dziennym ${ }^{66}$.

Należy podkreślić, że zgodnie z wolą ustawodawcy pełnienie terytorialnej służby wojskowej w WOT jest równoznaczne ze spełnieniem obowiązku zasadniczej służby wojskowej przez osoby podlegające obowiązkowi jej odbycia ${ }^{67}$.

Żołnierze zawodowi podejmujący służbę w szeregach WOT podlegają przepisom ustawy o służbie wojskowej żołnierzy zawodowych, na mocy której korzystają z przywilejów i świadczeń w takim samym zakresie jak pozostała część kadry zawodowej Sił Zbrojnych RP. Z kolei żołnierze terytorialnej służby wojskowej mogą liczyć na takie rozwiązania prawne, jak: prawo do uposażenia, zwrot kosztów przejazdów do i z miej-

http://promilitaria21.home.pl/aytoinstalator/joomla/aktualnosci-i-prawo/item/5835-17-x-wojsko-poszukuje50-kandydatow-na-podoficerow-wot (dostęp: 3.04.2018).

64 Można ją pełnić również w inne dni, stosownie do potrzeb Sił Zbrojnych RP, zgodnie z rocznym wykazem sporządzonym przez dowódcę jednostki wojskowej, w której żołnierz WOT odbywa służbę, uzgodnionym $\mathrm{z}$ tym żołnierzem. Służbę tę można także pełnić $\mathrm{w}$ trybie natychmiastowego stawiennictwa. Por. ustawa z dnia 16 listopada 2016 r. o zmianie ustawy o powszechnym obowiązku obrony Rzeczypospolitej Polskiej oraz niektórych innych ustaw, Dz.U. z 2016 r. poz. 2138.

65 Ibidem.

66 Ibidem.

67 Ibidem. 
sca odbywania służby rotacyjnej, dofinansowanie kosztów nauki, udział w szkoleniach i kursach, także podoficerskich i oficerskich, czy ochrona przed zwolnieniem z pracy pracownika powołanego do terytorialnej służby wojskowej. Poza tym każdy z nich otrzyma comiesięczny dodatek do uposażenia zasadniczego za „gotowość bojową", który w zależności od posiadanego stopnia wojskowego wynosi około 500-600 złotych. Również za udział w ćwiczeniach pobiorą oni ekwiwalent pieniężny ${ }^{68}$.

Żołnierze WOT mają również prawo do urlopów: wypoczynkowego, okolicznościowego i nagrodowego. Czas służby rotacyjnej zostanie im wliczony do wysługi emerytalnej. Legitymując się co najmniej trzyletnim stażem w tej formacji, mogą liczyć na pierwszeństwo w ubieganiu się o służbę kandydacką, zawodową czy stanowisko urzędnicze związane z obronnością ${ }^{69}$.

Pełniący terytorialną służbę wojskową są zobowiązani do przestrzegania tych samych przepisów kodeksu karnego, które stosuje się wobec żołnierzy innych rodzajów sił zbrojnych. Karane będzie między innymi poniżanie podwładnych czy znieważanie przełożonych. Każdy z nich zostanie też poddany corocznemu opiniowaniu służbowemu. Jego wynik ma decydować o przydatności „terytorialsa” do dalszej służby ${ }^{70}$.

\section{Podsumowanie}

Formacje Obrony Terytorialnej istnieją w większości państw w Europie i wielu krajach poza nią. Wszędzie stanowią ważny element systemu obronnego, efektywnie uzupełniający i wspomagający wojska operacyjne zarówno w czasie kryzysu (zagrożenia) i wojny, jak również w okresie pokoju. Jednocześnie są one czynnikiem integrującym społeczeństwo wokół szeroko rozumianej problematyki bezpieczeństwa, promującym postawy patriotyczne i obronne. Dlatego idea utworzenia w Polsce Wojsk obrony terytorialnej wydaje się zasadna i znajduje, jak można sądzić, akceptację wśród znacznej części naszych obywateli. Jednak podjęcie decyzji o wyborze konkretnej koncepcji obrony terytorialnej i sposobie jej realizacji powinno zostać poprzedzone pogłębionymi studiami, rzetelnymi analizami oraz szeroką, niepozorowaną dyskusją w ramach różnych grup eksperckich, zarówno wojskowych, jak i cywilnych. Wówczas byłaby szansa opracowania projektu możliwie optymalnego, eliminującego większość problemów, z jakimi aktualnie boryka się ta formacja.

W obecnie wdrażanej w Polsce koncepcji Wojsk Obrony Terytorialnej można dostrzec nie tylko zalety, lecz także wady.

Wśród tych pierwszych najczęściej wymienia się: istotne podniesienie ogólnego sta-

68 Ibidem; N. Sobiech, Jakie sa zadania Wojsk Obrony Terytorialnej, http://www.gazetaprawna.pl/ artykuly/1064527,macierewicz-wot-zadania-rekrutacja-struktura.html (dostęp: 3.02.2018).

${ }^{69}$ Ustawa z dnia 16 listopada 2016 r. o zmianie ustawy o powszechnym obowiązku obrony Rzeczypospolitej polskiej oraz niektórych innych ustaw.

70 Ibidem; M. Miłosz, Wojska Obrony Terytorialnej - 6 faktów na temat piatego rodzaju Sił Zbrojnych, http://wiadomosci.dziennik.pl/wydarzenia/artykuly/551045, wojska-obrony-terytorialnej-koszty-struktura. html (dostęp: 2.02.2018). 
nu ewidencyjnego Sił Zbrojnych RP w czasie pokoju, wykorzystanie potencjału kadrowego organizacji proobronnych w procesie rekrutacji ochotników do WOT, zwiększenie możliwości realizacji przedsięwzięć z zakresu zarządzania kryzysowego, zastosowanie czynników motywacyjnych przy naborze do terytorialnej służby wojskowej ${ }^{71}$.

Natomiast do tych drugich można zaliczyć między innymi: „drenaż” kadry zawodowej wojsk operacyjnych na rzecz formowanych jednostek OT, niższy poziom wyszkolenia wojskowego żołnierzy WOT w porównaniu do ich kolegów z innych rodzajów Sił Zbrojnych RP, brak odpowiedniej bazy szkoleniowej przeznaczonej dla WOT na terenie powiatów, szczupłą i nieadekwatną do potrzeb pododdziałów i oddziałów OT infrastrukturę wojskową, niewystarczającą siłę ognia jednostek OT, by mogły efektywnie wspierać pierwszoliniowe formacje Wojska Polskiego w strefie bezpośrednich działań bojowych, niedostatek środków transportowych będących w dyspozycji jednostek OT, przyjęcie zbyt krótkiego okresu (do 2019 roku) na osiągnięcie pełnego stanu osobowego WOT oraz stosunkowo duże nakłady finansowe na utworzenie WOT, które mogłyby zostać przeznaczone na wzmocnienie potencjału wojsk operacyjnych ${ }^{72}$.

\section{Bibliografia}

900 mln złotych w budżecie WOT na 2017 r. W roku kolejnym - 1,3 mld zł, http://www.defence24.pl/mon-900mln-zlotych-w-budzecie-wot-na-2017-r-w-roku-kolejnym-1.3-mld-zl (dostęp: 10.04.2018).

Zakres wiedzy teoretycznej obowiązujacej kandydata do Terytorialnej Stużby Wojskowej (tymczasowy), Warszawa 2017, http://warszawapraga.wku.wp.mil.pl/files/warszawa/file/wot/materialy-tsw.pdf (dostęp: 25.04.2018).

Byli specjalsi wyszkolq Obronę Terytorialna, http://www.dziennikpolski24.pl/aktualnosci/a/byli-specjalsi-wyszkola-obrone-terytorialna,11760011/ (dostęp: 7.03.2018).

CH.R., Wojsko poszukuje 50 kandydatów na podoficerów WOT,http://promilitaria.21.home.pl/aytoinstalator/joomla/aktualnosci-i-prawo/item/5835-17-x-wojsko-poszukuje-50-kandydatow-na-podoficerowwot (dostęp: 3.04.2018).

Formowanie brygad OT w Polsce centralnej, http://www.mon.gov.pl/aktualnosci/artykul/najnowsze/formowanie-brygad-w-polsce-centralnej-m2018-01-15/ (dostęp: 5.02.2019).

Glińska P., Kowalska-Sendek M., WOT - misja, struktura, szkolenie, http://www.polska-zbrojna.pl/home/ articleshow/22674?t=WOT-misja-struktura-szkolenie (dostęp: 19.03.2018).

http://wiis.org.pl/index.php?option=com_content@view=article@id=82:w-warszawa (dostęp: 11.02.2018). http://spwl.wp.mil.pl/57.html (dostęp: 5.04.2018).

Jakubczak R., Współczesne Wojska Obrony Terytorialnej, Bellona, Warszawa 2016.

Jednostki wojskowe, https://www.jednostki-wojskowe.pl (dostęp: 12.02.2018).

Kaleta W., Żołnierz w każdej wsi, „Polska Zbrojna” 2000, nr 15.

Kowalska-Sendek M., Byli specjalni utworza Mobilny Zespót Szkoleniowy WOT, http://www.polska-zbrojna.pl/home/articleshow/21694?t=Byli-specjalsi-utworza-Mobilny-Zespol-Szkoleniowy-WOT (dostęp: 20.03.2018).

Marczak J., Jakubczak R., Raport strategiczny: Sity Zbrojne RP w drugiej dekadzie XXI wieku. Koncepcja strategiczna Obrony Terytorialnej RP, AON, Warszawa 2014.

71 Wojska Obrony Terytorialnej. Stan obecny..., s. 25.

72 Ibidem, s. 26, 28-29. 
Michalak A., Cele, zadania, struktura i funkcje wojsk obrony terytorialnej w XXI wieku, „Bezpieczeństwo. Teoria i Praktyka" 2017, nr 3.

Miłosz M., MON zwiększyło górny limit żołnierzy WOT o 10 tys. ludzi. Zaraz po publikacji DGP, https:// wiadomosci.dziennik.pl/wydarzenia/artykuly/588,wot-mon-armia.html (dostęp: 10.02.2019).

Miłosz M., Wojska Obrony Terytorialnej - 6 faktów na temat piątego rodzaju sił zbrojnych,http://wiadomosci.dziennik.pl/wydarzenia/artykuly/551045, wojska-obrony-terytorialnej-koszty-struktura,html (dostęp: 2.02.2018).

MON: aktualnie w WOT stuży 11,6 tys. żotnierzy, https://www.wnp.pl/przemysl-obronny/mon-aktualnie-w-wot-sluzy-11-6-tys-zolnierzy,327297_1_0_0.html (dostęp: 10.02. 2019).

Polcikiewicz Z., Wojska Obrony Terytorialnej w systemie bezpieczeństwa narodowego Polski, http://cejsh. icm.edu.pl/cejsh/element/bwmetal.element.desklight-99a69fa5-32a6-42fc-8012-daa458d1c65f/c/Wojska_obrony_terytorialnej_399-413.pdf (dostęp: 5.02.2019).

Rochowicz R., Stara nazwa, nowa koncepcja, „Polska Zbrojna” 1999, nr 15.

Rok terytorialsów, http://www.polska-zbrojna.pl/home/artocleshow/24440?t=Rok-terytorialsow (dostęp: 16.02.2018).

Sobiech N., Jakie sa zadania Wojsk Obrony Terytorialnej, http://www.gazetaprawna.pl/artykuly/1064527,macierewicz-wot-zadania-rekrutacja-struktura.html (dostęp: 3.02.2018).

Tańska J., W sejmie podsumowano rok funkcjonowania WOT, http://www.polska-zbrojna.pl/home/ articleshow/24497?t=W-Sejmie-podsumowano-rok-funkcjonowania-WOT (dostęp: 21.02.2018).

Terytorialsi rozpoczynaja szkolenie indywidualne, http://www.mon.gov.pl/aktualnosci/artykul/najnowsze/ terytorialsi-rozpoczynaja-szkolenie-indywidualne-f2017-06-10/ (dostęp: 5.02.2019).

Terytorialsi zdobywaja oficerskie szlify, http://polska-zbrojna.pl/home/articleshow/24394?t=Terytorialsizdobywaja-oficerskie-szlify (dostęp: 19.04.2018).

Traktat o konwencjonalnych siłach zbrojnych w Europie/Treaty on Conventional Armed Forces in Europe, podpisany 19 listopada 1990 w Paryżu, „Zbiór dokumentów”/Recuil de Documents (PISM), 1991/XLVII.

Ustawa z dnia 16 listopada 2016 roku o zmianie ustawy o powszechnym obowiązku obrony Rzeczypospolitej Polskiej oraz niektórych innych ustaw, Dz.U. z 2016 r. poz. 2138.

Wojska Obrony Terytorialnej. Stan obecny. Pożadane kierunki zmian, oprac. M. Różański, A. Duda, J. Rajchel, T. Drewniak, J. Stróżek., Warszawa 2018, http://www.stratpoints.eu/publikacje/wojska-obrony-terytorialnejstan-obecny-i-pozodane-kierunki-zmian/ (dostęp: 5.02.2019).

WOT. Pierwszeństwo w powołaniu, http://www.mon.gov.pl/obrona-terytorialna/dolacz-do-nas/pierszenstwo-w--powolaniu-g2016-12-28/ (dostęp: 5.02.2019).

WOT. Procedury rekrutacji, http://www.mon.gov.pl/obrona-terytorialna/dolacz-do-nas/procedury-rekrutacji-r2016-12-28/ (dostęp: 5.02.2019).

WOT w systemie obronnym państwa, http://www.mon.gov.pl/obrona-terytorialna/pytania-i-odpowiedzi/wot-w-systemie-obronnym-panstwa-y2016-12-28 (dostęp: 5.02.2019).

WOT. Wymagania, http://www.mon.gov.pl/obrona-terytorialna/dolacz-do-nas/wymagania-f2016-12-28/ (dostęp: 5.02.2019).

WOT. Wyposażenie i uzbrojenie, http://www.mon.gov.pl/obrona-terytorialna/pytania-i-odpowiedzi/wyposazenie-i-uzbrojenie-I2016-12-28 (dostęp: 5.02.2019).

Wroński P., Wojska Obrony terytorialnej będa jeszcze liczniejsze. Macierewicz zapowiada 53 tys. żotnierzy za 3 lata, http://wyborcza.pl/7,75398,20975686,wojska-obrony-terytorialnej-beda-jeszcze-liczniejsze-antoni. html (dostęp: 5.02.2019).

Zadania WOT,http://www.mon.gov.pl/obrona-terytorialna/o-nas/zadania-wot-n2016-12-27 (dostęp:5.02.2019). 


\section{Development of Territorial Defence Forces}

Keywords: territorial defence, armed forces, light infantry, crisis management, irregular activities, territorial military service

Summary

Territorial Defence Forces (TDF) began their official activity on 1 January 2017. They are the fifth single service in the Polish Armed Forces next to Lang Forces, Air Force, Navy and Special Operations Forces. It has been established that the organization of TDF is going to be strictly related to the currently existing administrative division of the country, giving a total of 17 brigades. Ultimately, there are to be 53,000 soldiers within the ranks. In times of peace TDF should mainly be ready to execute crisis management activities, in times of war TDF should support regular Polish Army Forces in terms of direct warfare. 